\title{
Contrasting Ordovician high- and low-pressure metamorphism related to a microcontinent-arc collision in the Eastern Cordillera of Perú (Tarma province)
}

\author{
Arne P. Willner ${ }^{\text {a, b, }{ }^{*}, \text { Colombo C.G. Tassinari }}{ }^{c}$, José F. Rodrigues ${ }^{\text {d }}$, Jorge Acosta ${ }^{\text {, }}$, \\ Ricardo Castroviejo ${ }^{\mathrm{f}}$, Miguel Rivera ${ }^{\mathrm{g}}$ \\ a Institut für Mineralogie und Kristallchemie, Universität Stuttgart, Azenbergstr. 18, 70174 Stuttgart, Germany \\ ${ }^{\mathrm{b}}$ Institut für Geologie, Mineralogie und Geophysik, Ruhr-Universität, 44780 Bochum, Germany \\ c Instituto de Geociéncias da Universidade de São Paulo, Rua do Lago 562, CEP 05508-080, Brazil \\ ${ }^{\mathrm{d}}$ Faculdade de Engenharia, Universidade de Porto, Rua Dr. Roberto Frias, s/n 4200-465 Porto, Portugal \\ e Instituto Geológico Minero y Metalúrgico, Av. Canadá 1470, San Borja, Lima 41, Perú \\ ${ }^{\mathrm{f}}$ Universidad Politécnica de Madrid, Escuela Técnica Superior de Ingenieros de Minas y Energía, c/ Ríos Rosa 21, 28003 Madrid, Spain \\ ${ }^{g}$ Av. Belén 323, dpt.303, Lima 27, San Isidro, Perú
}

\section{A R T I C L E I N F O}

\section{Article history:}

Received 22 January 2014

Accepted 12 May 2014

Available online 24 May 2014

\section{Keywords:}

Garnet amphibolite

$\mathrm{Sm}-\mathrm{Nd}$ mineral isochron

High pressure

Microcontinent-arc collision

PT pseudosection

\begin{abstract}
A B S T R A C T
High-pressure conditions of $11-13 \mathrm{kbar} / 500-540{ }^{\circ} \mathrm{C}$ during maximum burial were derived for garnet amphibolite in the Tapo Ultramafic Massif in the Eastern Cordillera of Peru using a PT pseudosection approach. A Sm-Nd mineral-whole rock isochron at $465 \pm 24$ Ma dates fluid influx at peak temperatures of $\sim 600{ }^{\circ} \mathrm{C}$ and the peak of high pressure metamorphism in a rodingite of this ultramafic complex. The Tapo Ultramafic Complex is interpreted as a relic of oceanic crust which was subducted and exhumed in a collision zone along a suture. It was buried under a metamorphic geotherm of $12-13{ }^{\circ} \mathrm{C} / \mathrm{km}$ during collision of the Paracas microcontinent with an Ordovician arc in the Peruvian Eastern Cordillera. The Ordovician arc is represented by the western Marañon Complex. Here, low PT conditions at 2.4-2.6 kbar, 300-330 ${ }^{\circ} \mathrm{C}$ were estimated for a phyllite-greenschist assemblage representing a contrasting metamorphic geotherm of $32-40{ }^{\circ} \mathrm{C} / \mathrm{km}$ characteristic for a magmatic arc environment.
\end{abstract}

๑) 2014 Elsevier Ltd. All rights reserved.

\section{Introduction}

The major characteristics of the Andes are an almost continuous calc-alkaline igneous activity at the Pacific convergent margin throughout Phanerozoic times and the presence of innumerable pre-Mesozoic metamorphic basement areas throughout the entire length of the chain (e.g. Ramos and Aleman, 2000; Ramos, 2008, 2009, 2010). These basement areas represent deep-seated magmatic arcs, accretionary prisms and collision zones of microplates, where crustal growth, substantial crustal thickening and erosion occurred. Allochthonous microcontinents were recognized in the past decades as summarized by Ramos (2009). In many cases microcontinents were defined by the presence of suture zones that contain chains of disrupted ophiolitic bodies as in the case of the

\footnotetext{
* Corresponding author. Institut für Mineralogie und Kristallchemie, Universität Stuttgart, Azenbergstr. 18, 70174 Stuttgart, Germany. Tel.: +49 234 3224577; fax: +49234 3214433

E-mail address: arne.willner@rub.de (A.P. Willner).
}

Chilenia terrane (Ramos et al., 1986) or the Cuyania terrane (Ramos, 2004) at latitude $27^{\circ}-38^{\circ} \mathrm{S}$. A further proof for the presence of allochthonous terranes is the metamorphic evolution particularly of high pressure metamorphic rocks within the proposed suture zones of these microcontinents in the Andean basement (e.g. Casquet et al., 2001; Massonne and Calderón, 2008; Willner et al., 2011; Martínez et al., 2012; Massonne and Toulkeridis, 2012). A similar situation occurs in the Eastern Cordillera of Perú (Ramos, 2009), where the Ordovician magmatic arc is displaced from its position along the southern Peruvian coast towards a position considerably further inland (Fig. 1a). The Ordovician arc is represented within a metamorphic basement, part of the Marañon Complex (MC; Cardona et al., 2009; Chew et al., 2008). On the western border of this metamorphic complex, a chain of few small ultramafic bodies occurs which are scattered within the metamorphic basement (Fig. 1b). The biggest is represented by the Tapo Ultramafic Massif (TUM) near Tarma in the eastern Cordillera, which contains serpentinized peridotite, metagabbro with ocean ridge or ocean island chemical characteristics and podiform 